\title{
The Values Debate at the Nexus of Transnational Perspectives on Human Rights and Citizenship Education
}

\author{
Yvonne Hébert (University of Calgary), Glen Eyford (University of Alberta), \\ and France Jutras (University of Sherbrooke)
}

\begin{abstract}
Serving as introduction to the collection of papers in this issue, this paper takes up seven themes to situate each paper in the debates that characterize the field of citizenship education and to attempt to understand the linkages between values, human rights and citizenship education in a transnational era. The themes explore planetary philosophical perspectives; understand values as practice and human rights as foundational to values; set geopolitical considerations of values in postcolonial perspectives and pedagogical perspectives in transnational contexts; characterize citizenship education as a contested field; and reflect upon the relevance of transnationalism to the values debate. In a concluding note, we remark that negotiating multiple, transcultural and transnational frames of reference is not unusual for many youth today nor is it in many countries; and as such, is the very nexus of education for democratic living in a transnational and transcultural times.
\end{abstract}

Résumé. Jouant le rôle d'introduction à la série d'articles publiés dans ce numéro de la revue, cet article met en relief sept thèmes qui permettent de situer chaque article dans les débats qui caractérisent le champ de l'éducation à la citoyenneté, pour ainsi tenter de faire comprendre les liens entre les valeurs, les droits de la personne et l'éducation à la citoyenneté dans notre monde transnational. Ces thèmes portent sur l'exploration des perspectives philosophiques planétaires; la compréhension des valeurs dans la pratique et les droits humains comme fondements aux valeurs de la citoyenneté; le fait de considérer les aspects géopolitiques des valeurs dans une perspective postcoloniale et ses répercussions pédagogiques dans des contextes transnationaux; les caractéristiques de l'éducation à la citoyenneté comme champ faisant l'objet de critiques; et la réflexion sur le sens du transnationalisme dans le débat sur les valeurs. En conclusion, nous remarquons que le fait de considérer des cadres de référence multiples, transculturels et transnationaux n'est pas inhabituel pour de nombreux jeunes ni pour de nombreux pays. Cela constitue en soi le cœur dynamique d'où peut jaillir l'éducation pour la vie démocratique à notre époque caractérisée par le transnational et le transculturel.

\section{Introduction}

The question of values is one that reoccurs periodically in educational and policy circles, a question that is raised in our era within a global context of rapid political, economic, cultural, social and religious change. This question is at the heart of an intense and complex dynamic typical of democratic societies which are pluralistic, secular, and increasingly post-modern. Such societies are notably diverse in linguistic, cultural and religious terms, resulting from the impact of 
policy changes sensitive to increasing immigration and nations within the country (see, for example, Kymlicka \& Patten, 2003; Hébert, 2002; Kymlicka, 2000; Cairns et al. 1999; Kymlicka \& Norman, 1995).

The values debate today calls upon us to define what kind of world we want. In recent years, the values debate has become sharper and more acrimonious, especially in school contexts (McAndrew et al, 1997; Desaulniers, 2000). Generally speaking, students themselves are bearers of values which they construct upon social and familial experiences; and administrators and educators are confronted daily with decisions to make regarding the best possible response to conflicts of values that occur in educational institutions. In a context of globalization marked by the blurring of the frontiers and greater interconnectivity, the values debate calls into review the pedagogical dimension of education as well as citizenship policy.

Dealing with the potentiality of citizenship education, the broad themes of this collection generated synergy and partnerships at the 5th International CERN Forum. A wide range of papers examined human rights and what it means to be a citizen as foundational to values, debating issues of children's rights, diversity, transnationalism, culture, bilingual education, and the democratic implications of structural adjustment in developing countries. The values debate is taken up from several perspectives in this issue: philosophical, practice, human rights, geopolitical, and pedagogical. In this introductory article, each theme is briefly situated, linked and intertwined to citizenship which is equally contested in similarly diverse contexts.

\section{Philosophical Perspectives}

Does citizenship mean anything today, in a world of transnational enterprise? Responding to this incisive question, Jutras clarifies the frame of reference for citizenship education broadly. She situates her discussion in the context of the most recent educational reform in Québec which re-introduced citizenship education in history at the secondary level and in geography at the elementary level. Taking up a planetary perspective on human rights as the fundamental reference (Appendix), she argues that these are consistent with societal culture and ministerial direction. Noting the predominance of individual rights, Jutras dwells upon the development of the good person in relationship to the good citizen; this presages teachers' views of their educational mission, to develop social and moral persons. Recognizing that this is insufficient for democratic education, she weighs the rights of the person as individual, with those of the person as citizen, and of the person as moral being. Thus, she calls for critical education of citizens questing for social justice as the necessary orientation for schooling in a market economy.

2 Canadian and International Education Vol. 34 no. 1 - June 2005 
Reflecting upon global citizenship education in a postmodern context, Pouwels similarly dwells upon the international body of human rights as a fundamental reference for contemporary citizenship education (Appendix). Taking up an individual deliberative approach to values education in heterogeneous national contexts, he is situated particularly in the context of Council of Europe's efforts to develop European citizenship. Pouwels recognizes the embedded nature of values in everyday life, where implicit values are probably more important than explicit values. In this regard, he notes that the legitimisation of values has moved through nature, outside authorities and finally through human deliberation, whereby values are determined by humans through deliberations and negotiations. As a result, he views citizenship education through the lens of the critical democratic citizen for whom autonomy, social involvement, respect for others, and solidarity are important. School discipline, political participation, and labour militancy are of lesser or no importance.

\section{Understanding Values as Practice}

Given the broad concern in reduced rates of participation in political activity, including elections as noted by Jutras, it is interesting to note that citizens nevertheless value civic participation and community engagement, as reported by Chareka and Sears (pp. 50-58). In their study of political participation, both the native-born Canadians and African immigrant participants, female and male, see value in civic participation, are engaged in substantial satisfactory community based activities, but eschew participation in political organizations. Although these two populations offered different reasons, black participants identify colour and culture as barriers to political participation. Civic participation actualized as volunteering is however seen as a way of making contacts, enhancing quality of life and résumés, gaining employment, and as real citizen involvement. Nonetheless, as the authors point out, the withdrawal of ordinary citizens from the political public sphere is a threat to democracy, eroding its popular base and narrowing understanding of the significance of this type of engagement to formal politics and governance. Like many theorists, these participants clearly see community service as non-political and of a different order than formal political participation.

Conceptions of participation may however be influenced as early as elementary school, as $\mathrm{Wu}$ explains in this collection. A Chinese bilingual program in Edmonton resulted in the children seeing the Chinese language as an asset and feeling special in being Chinese. Such confidence also influences their vision of Canada as a multicultural society and their sense of belonging. These young people considered diversity, equality, freedom of being different, and sharing among cultures, to be the characteristics of a multicultural society. The grade six children understood complex concepts through their own life experiences and strongly believed that they could fit in such a multicultural society. 
Another study, of the conceptions of Ontario high school students, with respect to a list of events of historical significance, adds to the body of knowledge about what students know for sure about what is commonly taught in schools. According to Lévesque, Francophone and Anglophone secondary students offer different reasons for their choices. Anglophone students selected according to factors of disciplinary importance such as long or ephemeral; and relevance to an understanding of the past, to a symbolic past. By comparison, Francophone students are sensitive to the historical past, preferring those that refer to the historical significance in terms of patriotic or collective attribution; and importance for those who have lived an historical event, historical events of considerable value in francophone communities in minority contexts.

What is common however, in the responses and preferences of Jutras' teachers, Chareka and Sears' youth and adults, Lévesque's secondary school students, as well as Wu's children, is the focus of participants on being a good person, sensitive to their community context, as inherent to their citizenship. This philosophical position may have deleterious consequences on citizenship education for two reasons. One is that this reduces the argument to the individual rather than to the collectivity for the common good. The second is that being a moral person does not guarantee personal and group involvement in political participation and governance. Nor is it enough to prepare the necessary intellectual and disciplinary capacities of a competent and responsible person. A balance must be found between the responsibility imposed by shared historical memories and the need for a historical conscience. Lamentably, it is not enough to be a good person - to be a good citizen, one must not only be prepared or disposed, but one must act collectively, from a critical perspective of democracy that is both deliberative and participatory.

\section{Human Rights as Foundational to Values}

Establishing human rights as the basis of citizenship education is advantageous, as proposed by Howe (pp. 42-49), Jutras (12-22), and Pouwels (59-67). Such a move provides principled orientations for the formation of the good person and the good citizen, especially since a plethora of court cases in the past 10 to 15 years that have banished all mention of God from public schooling. Merging character education with citizenship education, most Canadian provinces and territories, as well as jurisdictions around the world, are developing programmes of study to go beyond the economic orientation of a fourth generation of citizenship education (Osborne, 1996), to implement and expand upon a fuller understanding of citizenship as participatory and deliberative. In spite of the riches of effective curricular materials developed and tested, for example by Covell and Howe $(2001,1999,1998)$, the links between human rights education, values education, and models or conceptions of citizenship have yet to be theoretised for the CERN research agenda. To date, a conceptual framework for citizenship has been developed (Gagnon \& Pagé, 1999; Pagé, 2001), as has an 
epistemological model of values for pluralist liberal societies (Wilkinson \& Hébert, 2003, 2001). Clearly, further research is needed to make the links explicit.

In positing certain human rights instruments as fundamental to value and citizenship education, its proponents in this issue do not problematise the universality of this corpus of human rights instruments. All agree that two international instruments are of particular significance, the UN Declaration of Human Rights (1948) and the UN Convention on the Rights of the Child (1989), for they assume the intrinsic worthiness of children as citizens (Figueroa, 2000). Children have a right to an education (article 29), rights in education (articles 12 to 16), and rights through education (article 5). Allowing children to enjoy their rights in the here and now, these human rights instruments respect children as individuals, recognize their human dignity and insist on their education and equality to all other bearers of human rights (Richardson, 2000). Nonetheless, taken up from transnational perspectives, it is possible to see that the posited universality of these instruments may be difficult to implement and monitor in developing countries with different conceptions of young people and organisation of family life (Verhellen, 2000, 1994).

There are many childhoods. Of five different conceptions of children and youth (Hébert \& Hartley, 2004), three hold particular relevance to notions of citizenship: the predominant economic conception of the child as asset, consumer, worker and commodity; the democratic conception of the child as citizen and active participant, and the strategic conception of the child as being capable of learning and solving problems autonomously. The last two views center the child and acknowledge his/her strategic competencies to negotiate identifications and learning. The strategic and economic conceptions however blur the distinction between children and adults, and foster metaphorical identities such as pilgrim, player, tourist, stroller and vagabond, passing through the landscape that is school and life in general (Bauman, 1996; Unruh, 2004). Moreover, these three conceptions recognize the transnational and transcultural nature of youth and children today within networks of family and friends that may span the world.

\section{Geopolitical Considerations of Values in Postcolonial Perspectives}

We understand ourselves to be living in a democratic age (Taylor, 2004). Yet the extent to which developed and developing countries conceptualize, implement and sustain a body of laws, policies and practices of citizenship remains to be examined especially from a transnational perspective. In this volume, Wilkinson documents and discusses several cases, namely the supranational European Union, the United States and Canada, paying particular attention to guarantees of freedom of expression and to exclusion of expression of this ideal in public places. At the intersection of transnationalism, migration 
and citizenship, Wilkinson uncovers the exhaustion of state-level citizenship in favour of an emerging macro-citizenship as belonging and rightful negotiation of civic responsibilities in a common public space, still under construction. The right of freedom and residence, right to vote and be elected in local elections, right to diplomatic protection in a third country, right to petition the European Parliament and to appeal to the European Ombudsman, all must be worked out while recognizing languages, cultures, religions, and legal processes for obtaining citizenship.

Pushing the debate further and taking up the view that the market is the negation of collective democratic action (Taylor, 2004), Mbele expresses deeply held objections to the colonial misapplication of democratic principles in a global economy, in a spirited analysis, presenting strong arguments for a total reform of the present imbalance of power, in favour of Africans. Understanding Europe and Africa to be mirror images of one another, as a being in common, he examines values that delegitimise race and universalise culture, as these conceptualise humans in a global ethos, with fluctuating identities as cosmopolitans, hybrids, nomads, métis, without anchor or territory, and with multiple ancestries. Detaching humans in this way makes it easy to pass continuously and irreversibly, from the desirable and the ideal, from the rational into the irrational, for a world without links. Mobility and perpetual flux are widely enhanced, in order to support corporate profit, leaving the worker with only individual formal rights. For Mbele, it is only civic education that could possibly turn this around, preparing young people to think critically and act collectively to achieve a socially and economically just world.

\section{Pedagogical Perspectives in Transnational Contexts}

Can education prepare students to live and work in our increasing technological societies, in a competitive world where decisions are made by industry and government, with little or no participation of the citizens who will be directly affected? This question is addressed by several contributors to this volume, one of whom proposes pedagogical approaches whereas others stress the relevance of researching students' conceptions of the political and their representations of others before proceeding.

Pedagogical Proposal: Pouwels explicitly and elaborately makes numerous recommendations for values education in a post-modern world, strongly arguing that civic education is to disobey unjust orders, is based on human rights education, takes up conflict resolution as pedagogy, embeds efforts in community, in meaningful activity in which the young citizen is an active inquirer.

Conceptions of what counts as political and as policy: According to Chareka and Sears' research findings presented briefly in this issue, civic education policies 
and programs seeking to extend conceptions of what counts as political and to develop the disposition to engage in formal politics must begin by explicitly examining the ideas students bring with them to class, and then engaging them in interpersonal dialogue with others whose conceptions are different (either directly or through readings, film, etc.). In this way, their ideas can be challenged, extended, and seen in a broader context.

Social Representations of Others: Social representations are understood here as common sense knowledge that is transmitted, learned, socially shaped and constructed through experiences and ways of thinking that organize practices, actions and ways of communicating, and that help to establish a vision of community participation, to structure the symbolic to social interaction, and to connect to collective representation (Lebrun, 2001). The social representations of democracy are relevant to popular understandings of the notion of citizenship, rights, participation and identities, with respect to sociological variations, political positionings and perceptions of the state, whether a supra-state like the European Union, a multi-national state like Canada, or a postcolonial state like Cameroon. Recommendations from Lévesque, Jutras, Mbele, $\mathrm{Wu}$, and others, stress the wisdom of exploring, examining and re-constructing education, by taking into account young people's social representations of themselves and of others, their understandings of concepts, historical events and their significance, as shaped by their communities of attachment, with significant distinctions to be negotiated, for example, between Francophone students in a minority context and Anglophone students, between immigrants and native-born Canadians.

\section{Citizenship Education as a Contested Field}

When the emerging Citizenship Education Research Network first met in 1998 to develop a cogent pan-Canadian research agenda, four major themes were identified as particularly meaningful for the creation of a corpus of data. In their most recent statement, these are:

Models of citizenship, typologies of citizens, and contexts in citizenship education;

Values of citizens and in citizenship education;

Behaviours, attitudes, skills, and knowledge in citizenship; and

Teaching practices in citizenship education (Hébert \& Pagé, 2002: 229).

While these themes are relevant to this collection of papers, they nonetheless stretch and go beyond to bring new issues to our attention. The philosophical, sociological and postcolonial perspectives in this collection enlarge the debate with planetary, transnational, and geopolitical frames of reference where human rights are centralized. Setting values at the nexus of this collection similarly goes beyond the CERN agenda to attempt to make explicit the links between the 
major themes. Thus, in this collection, discussions of the values and boundaries of citizenship take up two major dilemmas of citizenship education in pluralist societies. As discussed in Kymlicka (2003), these two characteristic concerns of citizenship continue to be very powerful in national political communities and in schools that play an important role in propagating this liberal/national model of citizenship.

Yet in this collection, the practice of citizenship moves beyond the reproductive role of schooling to dwell in its transformative purpose. Human rights education takes up conflict resolution as pedagogy and extends conceptions of what counts as political education. Explorations of young people's social representations of others and themselves are central to the reconstruction of education for democracy. Lived experiences in bilingual forms of education provide similar opportunities to challenge notions of common schools for nation-building and to develop difference as the heart of pluralist societies. In other words, language education is implicitly and explicitly also political education (Starkey, 1999). Thus, this collection begins to move the research agenda beyond aspects of education (knowledge and skill acquisition, attitude formation, participation in institutions) to political outcomes such as participation, partisan choice, and political identity (Emler \& Frazer, 1999), to make progress in coming to terms with the understandings of citizens, young and old, of political processes.

Nonetheless, although the research agenda and resulting understandings have been stretched, this collection does not include all possible issues in citizenship education. While a themed collection was created here and as a whole offers a reasonably cogent view of the field, what is included represents a significant part of thinking in the field of citizenship education but not all of it. Additional research is needed for example, on the role of organizations such as clubs, political parties and volunteer associations in the formation of citizens; on social networks as formative reference groups; on the availability in discourse and in practice of positions, analyses and political options within young citizens' consciousness; on the political outcomes of the organization of power in schools; and on whether or not curriculum matters in preparing politically literate citizens. Research is also needed on pedagogical issues, for example on the possibilities of educating effective citizens for all levels of political community; on the linguistic competencies for full participation in civil society which tends to function in the language of the majority in pluralist countries; and the acceptance of tradition and authority in institutions and in community, as compared to the promotion of autonomy, public reasonableness, and exposure to competing ways of life. In other words, the complex interplay between educational and political variables, between nationalist and pluralist views, is yet to be fully explored and comprehended. Moreover, despite the proliferation of research on citizenship education and human rights including children's rights (Moosa-Mitha, 2005), the field remains largely under-theorized. To balance and broaden the continuing power of liberal national conceptions, alternative models 
of citizenship and democratic education centred on difference as equality, are needed.

\section{On the Relevance of Transnationalism to the Values Debate}

The landscape of citizenship in plural societies today is being swiftly reshaped by a global migration pattern. Such scope has not been seen, for example in the Canadian West, since the completion of the railway in the late 1880s which served to bring immigrants to the vast Canadian prairies; to ship wheat to European markets; to bring British Columbia into Confederation; to establish an east-west pull to counteract the north-south attraction rife with bootleggers and border crossings (Friesen, 1984). This migration increased the population by over $400 \%$ in just a few decades (Troper, 2002). Phenomenal growth, then and now, call for new understandings of citizenship, forms of belonging and multiple attachments, the force of economic pressures, and the nature of human society and of governance.

Transnational realities for many young people call upon educators to develop among young people, more sophisticated understandings of history and social representations of self and others, while learning to live together in creative, constructive and strategic ways, as pointed out by the authors in this issue. Young people today live social, cultural, economic and strategic relations that are embedded in dynamic and yet temporal groups and networks (Massey, 1998). This view of social relations is of interest to the perspectives of democratic life and schooling in this volume, especially when these relations have the young person at the core of networks and when these provide authentic opportunities for learning everyday (Raffo \& Reeves, 2000). The changing dynamics within the lives of young people in the short, medium and long-term create new social relations and evolving individualized networks. Thus, systems of social relations support and constrain individual actions, educational outcomes, change and democratic development (Cotterell, 1996), while providing a broad base of constantly updated reflexive knowledge.

Having multiple, transcultural and transnational frames of reference is not unusual in the Canadian context and in many countries. To negotiate their difference, spatial attachments, and belongings, today's youth make use of diverse formulae of multiple identifications, sensitive to previous contexts, belief systems, ethnicities, languages, religions and cultures, while remaining strategically open to potentialities (Hébert, 2005). Thanks to technological advances, young people situate themselves with the art and essence of being simultaneously in more than one place and time. This then is at the very nexus of education for democratic living in an age of transnationalism and transculturalism. 


\section{References}

Bauman, Z. (1996). From pilgrim to tourist - or a short history of identity. In S. Hall \& P. du Gay (Eds.), Questions of Cultural Identity (pp. 18-36). London: Sage Publications.

Cairns, A. C., John C., Peter M., Hans J. M., \& David E. S. (Eds.). (1999). Citizenship, diversity and pluralism: Canadian and comparative perspectives. Montréal and Kingston: McGill-Queen's University Press.

Cotterell, J. (1996). Social networks and social influences in adolescence. London: Routledge.

Covell, K., \& Brian R. H. (2001). Moral education through the 3 Rs: Rights, respect and responsibility. Journal of Moral Education, 30, 29-41.

Covell, K., \& Brian, R. H. (1999). The impact of children's rights education: A Canadian study. The International Journal of Children's Rights, 7, 171-183.

Covell, K. \& Brian, R. H. (1998). Children's rights education curriculum resource. Sydney, N.S.: University College of Cape Breton Children's Rights Center.

Desaulniers, M. P. (2000). École, valeurs et laïcité : vers de nouvelles approches du mieux vivre-ensemble. Éducation Canada, 40, 33-37, \& 43 .

Emler, N. \& Frazer, E. (1999). Politics: the education effect. Oxford Review of Education, 25, 251-273.

Figueroa, P. (2000). Citizenship education for a plural society. In A. Osler (Ed.), Citizenship and democracy in schools: Diversity, identity and equality (pp. 4762). Stoke on Trentham, UK and Sterling, USA: Trentham Books.

Friesen, G. (1984). The Canadian prairies: A history. Toronto. The University of Toronto Press.

Gagnon, F. \& Pagé, M. (1999). Conceptual framework for the analysis of citizenship in liberal democracies: Vol. 1: Conceptual framework and analysis. Vol. II: Approaches to citizenship in six liberal democracies. Ottawa: Department of Canadian Heritage. Available at: http://canada.metropolis.net/research-policy/cern-pub/index.html

Hébert, Y. (2005). Transculturalism among Canadian Youth: Focus on Strategic Competence and Social Capital. In D. Hoerder, Y. Hébert \& I. Schmitt (Eds.), Negotiating Transcultural Lives: Belongings and Social Capital among Youths in Comparative Perspective (pp.105-130). Göttingen, Germany: V\& R Unipress.

Hébert, Y. \& William J. H. (2004). Why now? Personalisation and changing conceptions of childhood and youth, chapter 5, to appear in R. Miller \& T. Bentley (Eds.), Personalizing learning: The future of civil service reform (8pp). Paris: OECD.

Hébert, Y. (Ed.) (2002). Citizenship in transformation in Canada. Toronto: University of Toronto Press.

Hébert, Y. \& Pagé M. (2002). Citizenship education: What research for the future? In Y. Hébert (Ed.), Citizenship in transformation in Canada (pp. 228-247). Toronto: University of Toronto Press,.

Hébert, Y., \& Wilkinson, L. (2001). Values for pluralistic democratic societies. In M. Montané \& Y. Beernaert with the assistance of N. Denayrolles, D. Iduarte \& M. Travé (Eds.), Towards active citizenship: Connecting young citizens across Europe and the world. Barcelona: Universal Forum of Cultures 2004 and the Connect Initiative of the European Parliament.

Kymlicka, W. (2003). Two dilemmas of citizenship education in pluralist societies. In A. Lockyer, B. Crick \& J. Annette (Eds.) Education for democratic citizenship: issues of theory and practice (pp. 47-63). Aldershot: Ashgate Publishing Ltd.

Kymlicka, W. (1995). Multicultural citizenship: A liberal theory of minority rights. Oxford: Clarendon Press.

10 Canadian and International Education Vol. 34 no. 1 - June 2005 
Kymlicka, W. \& Patten A. (Eds.) (2003). Language rights and political theory. Toronto: Oxford University Press.

Kymlicka, W. \& Wayne N. (Eds.) (2000). Citizenship in diverse societies. Toronto: Oxford University Press.

Lebrun, M. (2001). Les représentations sociales. Des méthodes de recherche aux problèmes de société. Outrement : Les Éditions Logiques.

Massey, D. (1998). The spatial construction of youth cultures. In T. Skelton \& V. Gill (Eds.), Cool places: Geographies of youth cultures (pp. 121-129). London/New York: Routledge.

McAndrew, M., Maryse J., \& Coryse C. (1997). La prise en compte de la diversité culturelle et religieuse dans les normes et les pratiques de gestion des établissements scolaires : une étude explorative dans cinq provinces canadiennes. Revue des sciences de l'éducation, 23, 209-232.

Moosa-Mitha, M. (2005). A difference-centred alternative to theorization of children's citizenship rights. Citizenship Studies, 9, 369-388.

Norris, P. (Ed.) (1999). Critical citizens: Global support for democratic government. Oxford: Oxford University Press.

Osborne, K. (1996). Education is the best national insurance. Canadian and International Education, 25, 31-58.

Pagé, M. (2001). L'éducation à la citoyenneté devant la diversité des conceptions de la citoyenneté. In M. Pagé, F. Ouellet \& L. Cortesão (dir.) (pp. 41-54) L'éducation à la citoyenneté. Sherbrooke : Éditions du CRP, Faculté d'éducation, Université de Sherbrooke.

Raffo, C., \& Reeves, M. (2000). Youth transitions and social exclusion: Developments in social capital theory. Journal of Youth Studies, 3, 147-166.

Richardson, R. (2000). Human rights and racial justice: Connections and contrasts. In A. Osler (Ed.), Citizenship and democracy in schools: Diversity, identity, equality (pp. 79-89). Stoke on Trentham, UK and Sterling Books, USA: Trentham Books.

Starkey, H. (1999). Foreign language teaching to adults: Implicit and explicit political education. Oxford Review of Education, 25, 155-169.

Taylor, C. (2004). Modern social imaginaries. Durham and London: Duke University Press.

Troper, H. (2002). The historical context for citizenship education in urban Canada. In Y. Hébert (Ed.), Citizenship in transformation in Canada (pp. 150-161). Toronto: University of Toronto Press,

Unruh, D. (2003). Geographies of french immersion identities. Exit paper in completion of the final requirements for the M. Ed. degree, University of Calgary. Available at: http://www.ss.ucalgary.ca/ces/Gradworks/unruh\%20Paper/GradWorks\% 20Unruh\%20Darlene.htm

Verhellen, E. (2000). Children's rights and education. In A. Osler (Ed.), Citzenship and democracy in schools: Diversity, identity, and equality (pp. 33-43). Stoke on Trent, UK/ Sterling, USA: Trentham Books.

Verhellen, E. (1997). Convention on the rights of the child: Background, motivation, strategies, main themes. Leuven Apeldoorn: Garant.

Wilkinson, L., \& Hébert, Y. (2003). The values debate, citizenship policy, and education in Canada. Canadian Diversity/Diversité canadienne, 2, 39-41. 